\title{
SEROLOGICAL DIAGNOSIS OF TOXOPLASMOSIS: USEFULNESS Of IgA DETECTION AND IgG AVIDITY DETERMINATION IN A PATIENT WITH A PERSISTENT IgM ANTIBODY RESPONSE TO Toxoplasma gondii
}

Luciana C. BERTOZZI, Lisandra A. SUZUKI \& Cláudio L. ROSSI

\begin{abstract}
SUMMARY
We report the detection of specific IgA antibodies and the determination of $\operatorname{IgG}$ avidity in sequential serum samples from a patient exhibiting significant levels of Toxoplasma-specific IgM antibodies for seven years after the onset of the clinical symptoms of toxoplasmosis. IgM antibodies were detected by an indirect immunofluorescence test and by three commercial enzyme-linked immunosorbent assays (ELISA). Anti-T. gondii IgA was quantified by the $\alpha$-capture ELISA technique using a commercial kit. As defined by the manufacturer of the IgA ELISA test used, most patients with acute toxoplasmosis have antibody levels $>40$ arbitrary units per $\mathrm{ml}(\mathrm{AU} / \mathrm{mL})$. At this cut-off level, the patient still had a positive ELISA result $(45 \mathrm{AU} / \mathrm{mL})$ in a serum sample taken one year after the beginning of clinical manifestations. The IgG avidity-ELISA test was performed with the Falcon assay screening test (F.A.S.T ${ }^{\circledR}$ ) - ELISA system. Avidity indices compatible with a recent Toxoplasma infection were found only in serum samples taken during the first 5 months after the onset of the clinical symptoms of toxoplasmosis. These results show that the interpretation of positive IgM results as indicative of recently acquired toxoplasmosis requires additional laboratory confirmation either by other tests or by the demonstration of a significant rise in the antibody titers in sequential serum samples.
\end{abstract}

KEYWORDS: Toxoplasmosis; Immunodiagnosis; IgM; IgA; IgG avidity.

\section{INTRODUCTION}

Toxoplasmosis, an infection caused by the intracellular parasite Toxoplasma gondii, is generally asymptomatic or is associated with mild, non-specific clinical manifestations in immunocompetent subjects ${ }^{7,8}$. Serological diagnosis of acute toxoplasmosis is based on the demonstration of a significant increase in specific $\operatorname{IgG}$ antibody levels and/or the presence of specific IgM antibodies. However, the prevalence of high Toxoplasma IgG antibody titers among normal individuals in most populations ${ }^{10}$ and the sustained persistence of specific IgM antibodies in some persons ${ }^{1,3}$ have complicated the interpretation of serological tests when acute toxoplasmosis is suspected. Previous reports have shown that Toxoplasma-specific IgA antibodies are frequently detected in the early phase of toxoplasmosis ${ }^{2,9,12}$. However, the persistence of such antibodies following acute infection is still surrounded by considerable controversy. The determination of IgG antibody avidity represents an important additional serological marker because low- and high-avidity antibodies are found predominantly in recent and long-term infections, respectively. In recent years, a variety of immunoenzymatic assays for specific IgG have been adapted to estimate antibody avidity in several diseases, including toxoplasmosis ${ }^{4-6,11}$. In this article, we report the results obtained with the detection of specific IgA antibodies and the determination of $\operatorname{IgG}$ avidity in sequential serum samples from a patient with persistently elevated levels of specific IgM antibodies.

\section{MATERIALS AND METHODS}

Patient and serum samples

A 29-year-old man was admitted to the university hospital at the State University of Campinas (São Paulo State, Brazil) in September 1991, with a three-week history of malaise, mild fever, asthenia and myalgia. A general physical examination disclosed palpable and nontender axillary, right posterior cervical, and inguinal lymph nodes. Hematological tests showed a red blood cell count of $5.1 \times 10^{6} / \mathrm{mm}^{3}$, a hemoglobin level of $16.4 \mathrm{~g} / \mathrm{dL}$, a hematocrit of $49.3 \%$, and a white blood cell count of $8,500 / \mathrm{mm}^{3}$ ( $4 \%$ band cells, $35 \%$ segmented cells, $2 \%$ eosinophils, $4 \%$ monocytes and $55 \%$ lymphocytes). The platelet count was $140,000 / \mathrm{mm}^{3}$ and the blood sedimentation rate was $27 \mathrm{~mm}$ in the first hour. The only meaningful findings from serological studies were positive tests for toxoplasmosis: IgM-IIF 4,096; IgM-ELISA = reactive Treatment with pyrimethamine and sulfadiazine was initiated one week after the serological diagnosis of toxoplasmosis, and four weeks later, the clinical symptoms had disappeared. A total of 13 serum samples obtained from this patient from 1 month to 7 years after the onset of the clinical symptoms of toxoplasmosis were assayed for Toxoplasma-specific antibodies and for immunoglobulin $\mathrm{G}$ antibody avidity. 


\section{Tests for Toxoplasma antibodies}

The IgM-IIF and IgG-IIF tests were performed as described previously ${ }^{13}$. For the IgM-IIF test, all serum samples were pretreated with rheumatoid factor-absorbent (Behring, Marburg, Germany). IgM-IIF antibody titers $\geq 32$ were considered positive ${ }^{3}$. Anti-T. gondii IgM was also detected by three commercial ELISA techniques. The primary test used was ETI-TOXOK-M reverse (Sorin Biomédica, Saluggia, Italy). Serum samples taken from 3 months to 7 years after onset of the clinical symptoms of infection were also tested using two automated enzyme immunoassays: TOXO-M-EIA (Abbott Laboratories, Chicago, USA) and VIDAS Toxo IgM (BioMérieux, Marcy-l'Etoile, France). Anti-T. gondii $\operatorname{IgA}$ was measured by the $\alpha$-capture ELISA technique using a commercial kit (ETI-TOXOX-A) from Sorin Biomédica. According to the manufacturer of the above IgA ELISA, most patients with acute toxoplasmosis have antibody levels > 40 arbitrary units per $\mathrm{mL}$ (AU/mL). Levels ranging from 10 to $40 \mathrm{AU} / \mathrm{mL}$ cannot be regarded as negative and their importance must be interpreted in association with specific IgM and IgG determinations; levels < $10 \mathrm{AU} / \mathrm{mL}$ are regarded as negative. The ELISA techniques for $\operatorname{IgM}$ and $\operatorname{IgA}$ detection were performed according to the manufacturers' instructions.

\section{Avidity test}

The IgG avidity-ELISA test was performed with the Falcon assay screening test (F.A.S.T. ${ }^{\circledR}$ )-ELISA system using $6 \mathrm{M}$ urea in phosphatebuffered saline (PBS) to dissociate the low-avidity antibodies after the antigen-antibody interaction as described elsewhere ${ }^{11}$. The F.A.S.T.-
ELISA system uses polystyrene beads on sticks molded to the lid of a microtitration plate. For the assay, the beads were coated with a soluble antigen from sonicated $T$. gondii. A single dilution (1:21) of the serum samples being tested, the PBS-urea solution (or PBS as control), the conjugate (goat anti - human IgG-peroxidase) and the substrate system (3,3',5,5'-tetramethylbenzidine/hydrogen peroxide) were placed in standard microtiter plates. The sensitized beads were exposed to the reagents by immersion, after appropriate washing. All serum samples were run twice in triplicate. The avidity index was calculated as the mean absorbance of reactions in which the beads were exposed to urea divided by the mean absorbance of reactions in which the beads were not exposed to urea, and expressed as a percentage. Avidity indices $\leq 40 \%$ and $\geq 58 \%$ were considered as indicative of recent and long-term infections, respectively.

\section{RESULTS}

As shown in Table 1, the patient had a positive IgM-IIF result for toxoplasmosis $(\geq 32)$ in serum samples taken up to 4 years after the onset of clinical manifestations. A longer persistence of IgM was observed with ELISA techniques. All three Toxoplasma IgM-ELISA kits (Sorin, Bio Mérieux and Abbott) detected significant levels of specific antibodies up to the last serum sample obtained 7 years after the onset of the clinical symptoms of infection. A shorter persistence of IgA was observed when values $>40 \mathrm{AU} / \mathrm{mL}$ represented significant antibody levels. However, a significant $\mathrm{IgA}$ level $(45 \mathrm{AU} / \mathrm{mL})$ was found in a serum sample taken 1 year after the beginning of clinical manifestations. Avidity indices compatible with a recent infection were found in serum

Table 1

Serological results for sequential serum samples from a patient exhibiting a persistent IgM antibody response to $T$. gondii

\begin{tabular}{|c|c|c|c|c|c|c|c|}
\hline \multirow{3}{*}{ Time• } & \multicolumn{4}{|c|}{$\operatorname{IgM}$} & \multirow{3}{*}{$\frac{\mathrm{IgG}}{\mathrm{IIF}}$} & \multirow{3}{*}{$\begin{array}{c}\operatorname{IgA} \\
\text { ELISA } \\
(\mathrm{AU} / \mathrm{mL})\end{array}$} & \multirow{3}{*}{$\begin{array}{c}\text { IgG avidity } \\
\text { index }(\%)\end{array}$} \\
\hline & \multirow[t]{2}{*}{ IIF } & \multicolumn{3}{|c|}{ ELISA } & & & \\
\hline & & Sorin & Bio Merieux & Abbott & & & \\
\hline $1 \mathrm{mo}$ & 4,096 & $\mathrm{R}$ & ND & ND & 4,096 & $>160$ & 18 \\
\hline $3 \mathrm{mo}$ & 2,048 & $\mathrm{R}$ & $\mathrm{R}$ & $\mathrm{R}$ & 32,768 & $>160$ & 28 \\
\hline $5 \mathrm{mo}$ & 1,024 & $\mathrm{R}$ & $\mathrm{R}$ & $\mathrm{R}$ & 32,768 & 96 & 30 \\
\hline $8 \mathrm{mo}$ & 1,024 & $\mathrm{R}$ & $\mathrm{R}$ & $\mathrm{R}$ & 16,384 & 68 & 51 \\
\hline $10 \mathrm{mo}$ & 512 & $\mathrm{R}$ & $\mathrm{R}$ & $\mathrm{R}$ & 16,384 & 56 & 56 \\
\hline $1 \mathrm{y}$ & 256 & $\mathrm{R}$ & $\mathrm{R}$ & $\mathrm{R}$ & 16,384 & 45 & 60 \\
\hline $1.5 \mathrm{y}$ & 128 & $\mathrm{R}$ & $\mathrm{R}$ & $\mathrm{R}$ & 16,384 & 16 & 65 \\
\hline $2 y$ & 64 & $\mathrm{R}$ & $\mathrm{R}$ & $\mathrm{R}$ & 8,192 & 12 & 71 \\
\hline $3 y$ & 32 & $\mathrm{R}$ & $\mathrm{R}$ & $\mathrm{R}$ & 8,192 & 9 & ND \\
\hline $4 y$ & 32 & $\mathrm{R}$ & $\mathrm{R}$ & $\mathrm{R}$ & 4,096 & 8 & 82 \\
\hline $5 y$ & $<32$ & $\mathrm{R}$ & $\mathrm{R}$ & $\mathrm{R}$ & 4,096 & 6 & 83 \\
\hline $6 y$ & $<32$ & $\mathrm{R}$ & $\mathrm{R}$ & $\mathrm{R}$ & 2,048 & 7 & 82 \\
\hline $7 y$ & $<32$ & $\mathrm{R}$ & $\mathrm{R}$ & $\mathrm{R}$ & 2,048 & 8 & 84 \\
\hline
\end{tabular}

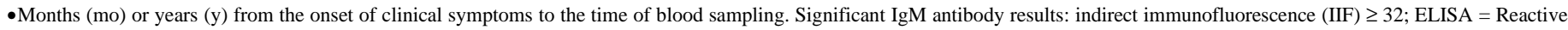

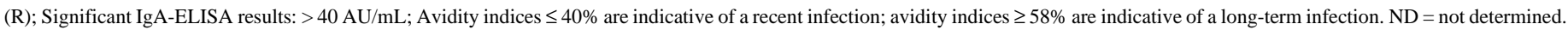


samples taken during the first 5 months after the onset of clinical symptoms, whereas indices compatible with the presence of a long-term infection were found in serum samples taken 1 or more years after the onset of clinical symptoms.

\section{DISCUSSION}

Most infections caused by $T$. gondii are asymptomatic and only a minority of patients with clinical evidence of infection exhibit signs and symptoms that cannot be attributed to the presence of the parasite ${ }^{7}$. Often, the diagnosis of a recently acquired Toxoplasma infection is based on the detection of specific IgM antibodies in a single serum sample. The use of tests with a low specificity and the presence of Toxoplasma - specific IgM in the chronic stage of infection have lead to unnecessary concern, particularly with regard to pregnant women. Several reports have emphasized the value of detecting Toxoplasma-specific $\operatorname{Ig} \mathrm{A}$ antibodies for the diagnosis of acute human toxoplasmosis ${ }^{2,9,12}$. The analysis of sequential serum samples from the above patient showed that when a cut-off of $10 \mathrm{AU} / \mathrm{mL}$ is used, IgA antibodies may be detected by ELISA long after the onset of clinical symptoms ( 2 years). In a previous study ${ }^{12}$, we screened serum samples from 51 patients with acute acquired toxoplasmosis for specific IgA antibodies. Fifty of the $51(99 \%)$ serum samples tested had antibody levels > $40 \mathrm{AU} / \mathrm{mL}$ (54 to $>160 \mathrm{AU} / \mathrm{mL})$. According to the manufacturer of the IgA-ELISA test used, most patients with acute toxoplasmosis have antibody levels $>40$ AU/mL. At this cut-off level, a shorter persistence of IgA was observed. However, the patient still had a positive ELISA result $(45 \mathrm{AU} / \mathrm{mL})$ in a serum sample taken one year after the beginning of clinical manifestations. In the present case, the usefulness of avidity determination in the serodiagnosis of a toxoplasmic infection was clearly demonstrated by the avidity index results obtained in the sequential serum samples from a patient exhibiting a persistent $\operatorname{IgM}$ antibody response. Avidity indices compatible with a recent Toxoplasma infection were found only in serum samples obtained during the first 5 months after the clinical symptoms of toxoplasmosis. These findings indicate that the serological diagnosis of acute toxoplasmosis may not be such an easy task. The interpretation of positive IgM results as indicative of recently acquired toxoplasmosis requires additional laboratory confirmation either by other tests or by the demonstration of a significant rise in the antibody titers in sequential serum samples.

\section{RESUMO}

Diagnóstico sorológico da toxoplasmose: utilidade da detecção de anticorpos IgA e da determinação da avidez dos anticorpos IgG em um paciente com uma resposta persistente de anticorpos IgM anti-Toxoplama gondii

No presente trabalho, são descritos os resultados da detecção de anticorpos específicos da classe IgA e da determinação da avidez dos anticorpos IgG em amostras sequenciais de soro de um paciente apresentando níveis significativos de anticorpos IgM anti-Toxoplasma gondii durante sete anos após o início das manifestações clínicas da infecção. Os anticorpos IgM foram detectados pelo teste de imunofluorescência indireta (IFI) e por três técnicas imunoenzimáticas (ELISA) comerciais. Os anticorpos IgA foram quantificados por uma técnica de ELISA de captura, utilizando um "kit" comercial. De acôrdo com as instruções do fabricante do "kit" utilizado para a pesquisa de $\operatorname{IgA}$, a maioria dos pacientes com toxoplasmose aguda apresenta níveis de anticorpos $>40$ unidades arbitrárias por $\mathrm{ml}(\mathrm{UA} / \mathrm{mL})$. Utilizando este parâmetro, o paciente, ainda, apresentou um resultado de ELISA positivo (45 $\mathrm{UA} / \mathrm{mL}$ ) em uma amostra de soro coletada um ano após o início das manifestações clínicas. A avidez dos anticorpos $\operatorname{IgG}$ foi determinada com uma técnica de ELISA, utilizando o sistema "Falcon assay screening test” (F.A.S.T. ${ }^{\circledR}$-ELISA). Índices de avidez compatíveis com uma infecção recente foram encontrados nas amostras de soros obtidas durante os primeiros 5 meses após o início dos sintomas clínicos da toxoplasmose. Os nossos dados mostram que a interpretação de resultados IgM positivos, como indicativos de toxoplasmose aguda, requer confirmação laboratorial com outros testes ou demonstração de um aumento significativo dos títulos de anticorpos em amostras sequenciais de soros.

\section{REFERENCES}

1. BROOKS, R.G.; McCABE, R.E. \& REMINGTON, J.S. - Role of serology in the diagnosis of toxoplasmic lymphadenopathy. Rev. infect. Dis., 9: 1055-1062, 1987.

2. DECOSTER, A.; DARCY, F.; CARON, A. et al. - IgA antibodies against P30 as markers of congenital and acute toxoplasmosis. Lancet, 2: 1104-1107, 1988.

3. DEL BONO, V.; CANESSA, A.; BRUZZI, P. et al. - Significance of specific immunoglobulin $\mathrm{M}$ in the chronological diagnosis of 38 cases of toxoplasmic lymphadenopathy. J. clin. Microbiol., 27: 2133-2135, 1989.

4. HEDMAN, K.; LAPPALAINEN, M.; SEPPALA, I. et al. - Recent primary Toxoplasma infection indicated by a low avidity of specific IgG. J. infect. Dis., 159: 736-740, 1989.

5. HOLLIMAN, R.E.; RAYMOND, R.; RENTON, N. et al. - The diagnosis of toxoplasmosis using IgG avidity. Epidem. Infect., 112: 399-408, 1994.

6. JENUM, P.A.; STRY-PEDERSEN, B. \& GUNDERSEN, A. - Improved diagnosis of primary Toxoplasma gondii infection in early pregnancy by determination of antitoxoplasma immunoglobulin G avidity. J. clin. Microbiol., 35: 1972-1977, 1997.

7. KEAN, B.H. - Clinical toxoplasmosis: 50 years. Trans. roy. Soc. trop. Med. Hyg., 66: 549-571, 1972

8. KRICK, J.A. \& REMINGTON, J.S. - Toxoplasmosis in the adult: an overview. New Engl. J. Med., 298: 550-553, 1978.

9. LE FICHOUX, Y.; MARTY, P. \& CHAN, H. - Les IgA sériques spécifiques dans le diagnostic de la toxoplasmose. Ann. Pédiat., 34: 375-379, 1987.

10. REMINGTON, J.S. \& DESMONTS, G. - Toxoplasmosis. In: REMINGTON, J.S. \& KLEIN, J.O., ed. Infectious diseases of the fetus and the newborn infant. Philadelphia, W.B. Saunders, 1990. p. 89-195.

11. ROSSI, C.L. - A simple, rapid enzyme-linked immunosorbent assay for evaluating immunoglobulin G antibody avidity in toxoplasmosis. Diagn. Microbiol. infect. Dis., 30: 25-30, 1998.

12. TAKAHASHI, E.E.H. \& ROSSI, C.L. - Use of three immunological techniques for the detection of Toxoplasma sp IgA antibodies in acute toxoplasmosis. J. clin. Path. 47: 1101-1104, 1994.

13. WELCH, P.C.; MASUR, H.; JONES, T.C. et al. - Serologic diagnosis of acute lymphadenopathic toxoplasmosis. J. infect. Dis., 142: 256-264, 1980.

Received: 07 January 1999

Accepted: 08 March 1999 